\title{
Correction to: Regulators of glucose uptake in thyroid cancer cell lines
}

Shabnam Heydarzadeh ${ }^{1}$, Ali Asghar Moshtaghie ${ }^{1}$, Maryam Daneshpour ${ }^{2}$ and Mehdi Hedayati ${ }^{2 *}$ (i)

\section{Correction to:Cell Communication and Signaling (2020) 18: 83 \\ https://doi.org/10.1186/s12964-020-00586-x}

Following publication of the original article [1], the authors identified an error in the author name of Maryam Daneshpour.

The incorrect author name is: Maryam Daneshpoor.

The correct author name is: Maryam Daneshpour.

\section{Author details}

'Department of Biochemistry, School of Biological Sciences, Falavarjan Branch Islamic Azad University, Isfahan, Iran. ${ }^{2}$ Cellular and Molecular Endocrine Research Center, Research Institute for Endocrine Sciences, Shahid Beheshti University of Medical Sciences, Tehran, Iran.

Published online: 25 January 2022

\section{Reference}

1. Heydarzadeh S, Moshtaghie AA, Daneshpour M, et al. Regulators of glucose uptake in thyroid cancer cell lines. Cell Commun Signal. 2020;18:83. https://doi.org/10.1186/s12964-020-00586-x.

\section{Publisher's Note}

Springer Nature remains neutral with regard to jurisdictional claims in published maps and institutional affiliations.

*Correspondence: hedayati@endocrine.ac.ir; hedayati47@gmail.com

${ }^{2}$ Cellular and Molecular Endocrine Research Center, Research Institute

for Endocrine Sciences, Shahid Beheshti University of Medical Sciences, Tehran, Iran

Full list of author information is available at the end of the article original author(s) and the source, provide a link to the Creative Commons licence, and indicate if changes were made. The images or other third party material in this article are included in the article's Creative Commons licence, unless indicated otherwise in a credit line to the material. If material is not included in the article's Creative Commons licence and your intended use is not permitted by statutory regulation or exceeds the permitted use, you will need to obtain permission directly from the copyright holder. To view a copy of this licence, visit http://creativecommons.org/licenses/by/4.0/. The Creative Commons Public Domain Dedication waiver (http://creativecommons.org/publicdomain/zero/1.0/) applies to the data made available in this article, unless otherwise stated in a credit line to the data. 